\title{
Long-Run Performance Following Corporate Outsourcing Transactions
}

\author{
Ning Gao (Corresponding author) \\ Assistant Professor, Finance, Business Economics and Legal Studies Department \\ Hagan School of Business, Iona College, 715 North Avenue, New Rochelle, NY, U.S.A. \\ Tel: 1-914-633-2126 E-mail: ngao@iona.edu
}

Received: September 10, 2012

Accepted: September 13, 2012

Online Published: September 14, 2012

doi:10.5430/bmr.v1n4p1

URL: http://dx.doi.org/10.5430/bmr.v1n4p1

\begin{abstract}
This paper primarily focuses on testing the long-run impact of outsourcing deals on the value of contract signatories. The long-run post-event changes in both stock and accounting related performance are examined. We find that in the long run client firms realize significantly positive buy-and-hold abnormal stock returns on average when compared with different groups of control firms. We also find evidence that client firms experience significant improvement in operating efficiency in three years after the contract effectiveness. Our findings suggest that outsourcing contracts are beneficial for client firms in the long run and this benefit is reflected by their ex post stock and accounting performance.
\end{abstract}

Keywords: Outsourcing, Long-run performance, Stock performance, Accounting performance

\section{Introduction}

As the business environment becomes more and more competitive and uncertain, companies keep seeking ways to gain economic efficiency and share business risks. Outsourcing is one of the solutions. During the last 15 years, with the growing interest of industry forums as well as other groups such as consultants and academics, outsourcing has developed to both an important business approach and a very popular strategic management initiative. Figures 1 and 2 are year-by-year graphs of the frequency and the value (in 2000 dollars) of outsourcing deals signed by client firms--which outsource their services to a different party, which we call vendors--listed on the US markets from 1990 to 2003 (Note 1). The figures suggest that both outsourcing frequency and contract value--the amount client firms pay to the vendors--have grown substantially during this period, especially after 1999. There are some variations for contract values in the recent past. But all in all, both variables follow increasing trend over time (Note 2).

\section{[Figure 1 here]}

[Figure 2 here]

The early outsourcing literature employs transaction cost economics (Coase, 1937; Williamson, 1979) as the primary theoretical lens to examine outsourcing arrangements. Transaction cost economics suggests that the costs and difficulties associated with market transactions sometimes favor hierarchies (or in-house production) and sometimes markets as an economic governance structure. According to Coase (1937), the limits of the firm are determined by the relative of the production costs inside the firm as compared with the costs of using the market. In Williamson (1985), the transactions costs are partly attributed to supplier hold-ups after customers have already invested in relationship specific assets. Thus, when hold-up problems are very costly, internal hierarchies are more advantageous. The hold-up problem is a situation where two parties (such as a supplier and a manufacturer or the owner of capital and workers) may be able to work most efficiently by cooperating, but refrain from doing so due to concerns that they may give the other party increased bargaining power, and thereby reduce their own profits. Grossman and Hart (1986) formulate a theory of vertical integration. Vertically integrated companies in a supply chain are united through a common owner. Usually each member of the supply chain produces a different product or (market-specific) service, and the products combine to satisfy a common need. The crucial contribution of their paper is to give theoretically rigorous definition of asset ownership and highlight the importance of contractual incompleteness. Their theory assumes that contracts cannot be fully specified, and emphasizes the scarcity of ownership incentives for remedying incentive problems that arise because of incomplete contracts. Grossman and Helpman (2002) theoretically examine a firm's decision to produce in-house or outsource. They model the "make or buy" decision as 
a trade-off between diseconomies of scope and the transaction costs that stem from search frictions and incomplete contracts. They find that, where the cost advantage of specialized component producers is large and their bargaining power vis-à-vis specialized final producers is great, outsourcing is more likely to emerge in a stable equilibrium the greater is the substitutability between varieties of final goods.

The conventional wisdom from transaction cost economics evolves slowly and firms begin to recognize that the overall production costs of managing their own internal operations may well be reduced by outsourcing due to considerable economies of scale available to large vendors such as IBM. Indeed, one of the key benefits of outsourcing is that economies of scale allow organizations to cost-effectively tap into specialized skills. Outsourcing is also being rapidly embraced by newly deregulated industries: telecommunications companies in the 1980s' and public utility companies in the 1990s' (Sharpe, 1997). As suggested by Sharpe (1997), "outsourcing did not emerge as the consequence of a sudden technical breakthrough, nor did it grow out of a best selling book by a well-known management guru. Rather, it was the result of market forces that emerged in response to demands for more efficient ways to address organizational competitiveness".

Outsourcing research also emphasizes on how the ideal contract should be negotiated, written, and enforced (Chaudhury et al., 1995). Agency theory provides a valuable theoretical framework to analyze the relationship between contract parties. The principal-agent problem concerns the difficulties in motivating one party (the "agent"), to act on behalf of another (the "principal"). The work of Quinn and Hilmer (1994) is aimed primarily at getting organizations to think strategically about outsourcing. In this most widely known article entitled, "Strategic Outsourcing", Quinn and Hilmer make the argument that the potential offered by outsourcing is optimized when outsourcing enhances a "core competency" business strategy. When correctly or optimally combined, core competency and extensive outsourcing strategies provide more flexibility, greater efficiency, and better responsiveness to customer needs at lower costs. Most importantly, strategic outsourcing provides organizations competitive edges in the long run. This strategic outsourcing theory is well received by corporate decision makers. For example, in July 1991, when LaBarge Inc. signed a five-year outsourcing contract worth \$2.1 million with McDonnell Douglas Co, William Maender, LaBarge's vice president said that "it is an effort to improve operating efficiency, control costs, standardize practices among plants and comply with the demanding government reporting requirements of manufacturing for the defense market." In another example when Affiliated Computer Services Inc. (ACS) announced the renewal of a comprehensive information technology (IT) outsourcing agreement with Affiliated Health Services of Mt. Vernon, Washington in January 2000, Tom Litaker, CFO of Affiliated Health Services said that "ACS has the experience and expertise to integrate technology with our business and help us reach our goals in the future. We expect ACS' broad range of services and industry knowledge to bring us efficiency and cost effectiveness in operations as we focus on providing the best possible care to our constituents" (Note 3).

In summary, the rationale for firms to practice outsourcing is that outsourcing helps organizations to increase operating efficiency, reduce operating costs, whilst achieving an increased focus on core competencies. This paper addresses the question of whether outsourcing affects firms' performance subsequent to the contract effectiveness. Specifically, we investigate the long-term stock and accounting performance of both signatory parties.

In this paper we employ a unique data set to examine the ex-post long-run changes in both the stock and accounting related performance, where stock performance is measured by the buy-and-hold returns, and accounting operating performance is proxied by five measures: sales efficiency (SALEFF), which is the real sales divided by the number of employees; income efficiency (IEFF), which is the operating income divided by the number of employees; CGSREV, which is the costs of goods sold divided by sales; NIREV, which is the net income divided by sales; and asset turnover (ASST), which is sales divided by book value of assets. We find that in the long run client firms realize significantly positive buy-and-hold abnormal stock returns. Our results also show that there is a significant improvement in the operating efficiency of client firms, relative to their industry medians and a set of control firms, following the contracts taking effect. Collectively, our findings suggest that outsourcing contracts are beneficial to contract clients in the long run. To our best knowledge, this is the first study to investigate the effectiveness of outsourcing contracts of US listed corporations from the long-term financial market and accounting performance perspectives.

This article extends extant finance and information systems (IS) literatures at least in two directions. First, it is the first to test whether the outsourcing arrangements benefit contract parties in the long run by studying their long-term stock and accounting performance. Secondly, we investigate the impact of country of origin of the vendors for the outsourcing contracts. 
The remainder of the paper is organized as follows. Section 2 discusses the previous research related to our study. Section 3 describes the sample and the methodologies used in the analysis of the impact of outsourcing. Empirical results and the interpretation of the results are reported in Section 4. Section 5 offers some robustness tests. Section 6 addresses limitations of the paper and Section 7 concludes.

\section{Previous research}

Theoretically, outsourcing has been extensively investigated up to date. But only few empirical papers have tested outsourcing. Abraham and Taylor (1996) are one of them. Their paper explores several different reasons for outsourcing, including savings on wage and payment benefits, transfer of demand uncertainty to outside contractors, and access to specialized skills and inputs that the organizations cannot possess themselves.

Several other papers as well as our first paper employ event study methodology to investigate short-run stock market reactions to corporate outsourcing contract announcements. Hayes et al. (2000) analyze the effect of announcing to outsource all or a portion of a firm's IS functions on the capital market value of the client firm. Using a sample of 77 client firms that announce IS outsourcing arrangements, their main results are as follows: For a one-day window (the day after the announcement day), there are statistically significantly positive abnormal stock returns for both small firms and service firms. Finally, their multivariate regressions provide further support of the size and industry impact on client firms' announcement period abnormal returns. Farag and Krishnan (2003) examine IT outsourcing deals announced between January 1994 and August 2001. They find positive market reactions to strategic sourcing projects. Ahmad (2004) finds that innovative outsourcing announcements, on average, enjoy a more positive market reaction than those frequent or multiple announcements. Gao (2009) examines outsourcing announcements during the period from 1990 to 2003 and finds that that the contract announcements are associated with significantly positive average abnormal stock returns for client firms when their sizes are small, when they outsource to bigger vendors, when they are opaque firms and need to focus on their core activities, and when their liquidity levels are low; vendor firms as a whole group realize significant positive market value gains.

The current paper tests the subsequent performance of outsourcing contract signatories. Girma and Gorg (2002) also address subsequent effects of outsourcing. But our tests are different from theirs. First, they use UK manufacturing establishment level data; while we use US public firm level data. Secondly, they analyze both the determinants of an establishment's decision to outsource and the subsequent effects of outsourcing on the establishment's productivity; while we focus on subsequent effects of outsourcing on firms' performance. Finally, their performance measure is labor or total factor productivity (TFP); while we use stock and accounting performance measures.

\section{Data and methodologies}

\subsection{Sample construction}

A total sample of 1071 outsourcing contracts signed by US publicly listed firms for the period 1990-2003 was drawn from Factiva, a Dow Jones \& Reuters Company, which provides world-class global content, including Dow Jones and Reuters newswires and The Wall Street Journal. We focus on testing the long-term performance in this paper.

In our original sample, client and vendor firms can be public, private firms or non-profit organizations. Sometimes client firms are governmental entities such as US Army. Next the following criteria are applied to client (vendor) firms: (1) they are NYSE, AMEX or Nasdaq listed firms with data from the Center for Research in Security Prices (CRSP) to calculate their stock returns; (2) they have data available in Compustat on a consolidated basis; (3) there should be no other financial events announced by the firm around the outsourcing contract announcement days (Note 4); We need the data from CRSP to analyze stock returns around the announcements of the outsourcing contracts. The Compustat data in one year before contract effectiveness are needed for our sample statistics and multivariate regressions.

\section{[Table 1 here]}

Our sample summary statistics are presented in Table 1. Panel A and B show that client firms are relatively bigger in size compared to vendor firms, with both mean and median sales and market value of equity (MVE) bigger than those of vendors. We further report Tobin's Q (market value of assets-to-replacement cost of assets) ratios for client frims (Note 5). The mean and median Q ratios of clients are both greater than 1. According to Lang and Litzenberger (1989), under certain assumptions, having a Tobin's Q value of less than 1 (low Q) is a sufficient condition for a firm to be categorized as over-investing. The fact that client firms are mainly high $\mathrm{Q}$ firms suggests that they are unlikely to be over-investing, but rather likely to have high growth opportunities. Figure 1, which depicts the fast growing trend of outsourcing over our sample period, may proxy for an increase in growth options. 
Table 1, Panel C describes characteristics of the deals in our sample. The average contract spans approximately 6 years. The mean contract value is $\$ 828.59$ million and the maximum contract value is $\$ 30$ billion (Note 6). Finally, the mean contract value per year is $\$ 140.27$ million, and the median of this item is $\$ 27.89$ million. All the information provided in Panel C suggests that these outsourcing contracts are big deals in general.

Panel D reports some of the sub-sample contracts. In $13.73 \%$ of the deals, client firms renew their outsourcing contracts with the previous vendors. About $12.14 \%$ of the contracts are signed by governmental entities as client firms. In only $5.71 \%$ of the deals, US client firms outsource to foreign vendors. Finally, about $80.71 \%$ of the deals involve US client firms outsource to US vendors.

Next, Panel E and Panel F of Table 1 report the top 4 major industry groups of client and vendor firms. The top three outsourcing industries are also the top three industries providing outsourcing services, only in a slightly different order. These industries are also the industries which have experienced rapid growth in the past 15 years.

Lastly, since the same client firm can outsource in different years and the same vendor can contract with several different client firms in a given year, the client and vendor firm relationship is not one-on-one. In order to avoid the influences of multiple contracts when we perform long-run tests, for each of the client (vendor) firm, we require that firm not sign another contract in three years surrounding the contract effectiveness. So that leaves 339 client firms and 235 vendors in our long-term analysis sample.

\subsection{Calculating long-term buy-and-hold stock returns}

For all the outsourcing events in the final sample, we define the contract effective day as event day zero. Trading dates before the effective day are denoted with a negative sign and those after are denoted with a positive sign (for example, 5 trading days before the effective day is referred to day -5). Using the CRSP daily tapes, we follow each client (vendor) firm from day zero until the earlier of its delisting date (If a firm is delisted prior to its anniversary date, we truncate its total return on that date), the contract's third anniversary, or the last day of CRSP-listed trading. We define a year as twelve 21-trading day intervals (252 days). A three-year window (756 trading days) is used in order to facilitate comparisons with other studies. Thus, the percentage buy-and-hold return for firm $\mathrm{i}$ is,

$$
R_{i T}=\left[\prod_{t=1}^{T}\left(1+r_{i t}\right)-1\right]
$$

where $T$ is the earlier of the last day of CRSP-listed trading or the end of the three-year window, and $r_{i t}$ is the return for firm $i$ on date $t$.

For each firm in the sample, we choose a matching (control) firm which is selected by using a variation of the matching procedure suggested by Barbor and Lyon (1996). They suggest that if the tests of interest are designed to detect abnormal performance following an event, sample firms should be matched with control firms based on pre-event performance as of year minus one. Barber and Lyon (1997) provide evidence that the procedure of matching sample firms to control firms of similar sizes and book-to-market ratios gives well-specified test statistics and yields more powerful, and unbiased test statistics than other matching procedures. Our matching procedure attempts to match client (vendor) firms with control firms on the basis of several variables. In particular, we select control firms based on size, size and book-to-market effects.

Size-matched firms are selected from all public companies in Compustat at the end of the year prior to the contract effective year, excluding sample firms. The size matched firm is the firm closest in market capitalization to the client firm. When matching on size and book-to-market ratios, we use Compustat firms to select the subset of firms that have market equity values within $30 \%$ of the market equity value of the sample firm. This subset is then ranked again according to book-to-market ratios. The size and book-to-market matched firm is the firm with the book-to-market ratio, measured at the end of the year prior to the contract effective year, which is closest to the client (vendor) firm's ratio. Matched firms are included for each sample firm for the full 3-year holding period or until the earlier of the last day of CRSP-listed trading of sample firms, whichever occurs sooner. If a matching firm is delisted before the ending date for its corresponding sample firm, a second (and, if necessary, third, fourth, etc.) matching firm is spliced in after the delisting date of the first matching firm. The replacement firm is the non-sample firm with size (size and book-to-market) at the original ranking immediately next to the original matching firm. Matching this way, a survivorship bias can be excluded.

Buy-and-hold abnormal returns are defined as the average equally weighted paired differences between buy-and-hold returns of sample firms and those of matching firms. That average of difference equals 0 if sample firms do not have 
better long-run stock performance compared to their control firms. The average $\tau$-year abnormal buy-and-hold return is measured as,

$$
R_{\tau}=\frac{1}{n} \sum_{i=1}^{n}\left(R_{i T}-R_{m T}\right)
$$

where $R_{i T}$ is the percentage buy-and-hold return on firm $i$ for holding period $T . R_{m T}$ is the percentage buy-and-hold return on firm $i$ 's matching firm for the same holding period $T . n$ is the number of sample firms in the sample. To be precise, the 3-year holding period for firm $i$ is the minimum of either 3 years or the portion of this time during which it is listed on the CRSP tapes.

\subsection{Measuring changes in accounting performance}

From both academic and anecdotal evidence, the often cited motivation for outsourcing is to increase the focus of the core operation of the client firms, thus improving their operating efficiency. To examine whether there are changes in operating efficiency after outsourcing transactions, we follow similar testing proxies as in Megginson et al. (1994). Specifically, operating efficiency is proxied by five measures: sales efficiency (SALEFF), which is the sales divided by the number of employees; income efficiency (IEFF), which is the operating income divided by the number of employees (Note 7); CGSREV is costs of goods sold divided by sales; NIREV is net income divided by sales; and asset turnover (ASST), which is sales divided by total assets (Note 8). Define contract effective year as year zero, we calculate these five ratios for our sample firms and their matching firms for one year prior to the contract effective year (year -1) and three years (year 3) after. For each year, we define the adjusted performance measure as the sample firm's ratio minus the benchmark ratio. Because of skewness and the potential influence of outliers when using accounting ratios, we follow Loughran and Ritter (1997) and focus on median values.

Two groups of benchmarks are used. To control for industry effects, the operating efficiency measures are adjusted by subtracting the median value of the corresponding measures for all firms in the primary two-digit SIC industry in which the firm was active one year before the event. A two-digit industry definition is used because Clarke (1989) has shown that the two-digit definition captures similarities among firms as effectively as industry definitions based on three- or four- digit SIC groupings.

Then a matching-firm approach is used to facilitate comparisons of industry-adjusted operating efficiency. The specific matching algorithm follows a similar matching method of Fee and Thomas (2004). For example, in the case of SALEFF, we first identify all firms on Compustat that are not in our sample. For these firms, we identify the firms with the same first two-digit SIC code as our sample firm, asset size at the end of year -1 between $25 \%$ and $200 \%$ of the sample firm, and SALEFF between $90 \%$ and $110 \%$ of the sample firm (Note 9). From these firms we choose as the matching firm the company with SALEFF closet to that of our sample firm. If no firm meets these criteria, then we relax the SALEFF screen to between $70 \%$ and $130 \%$ of the sample firm. If no matching firm is available this time, we relax the industry screen to require only a one-digit SIC code match, and then relax the SALEFF requirement accordingly. If there is still no match, we eliminate the industry matching requirement and match on size and SALEFF. Finally, if no match is available after eliminating the industry matching requirement, we eliminate the size requirement and match purely on SALEFF. The rest operating performance measures are matched in the same way. In all but $4 \%$ of the cases, client firms have matches at the two-digit SIC level, 1.9\% at the one-digit SIC level, $2 \%$ using size and performance, and $0.1 \%$ using only performance.

\subsection{The Fama-French three-factor model and calendar time portfolios}

As opposed to the event-time approach such as calculating buy-and-hold returns, the calendar-time approach takes into account the real date of the event and it offers some advantages. First, this approach eliminates the problem of cross-sectional dependence among sample firms because the returns on sample firms are aggregated into a single portfolio. Second, the calendar-time portfolio methods yield more robust test statistics in random samples, though this method is generally misspecified in nonrandom samples. We use the three-factor model developed by Fama and French (1993). The calendar-time period starts in 1990 and ends on the last day of CRSP-listed trading when the 36-month post-event window is considered. For each calendar month, we calculate the return on a portfolio composed of firms that has an event within our calendar window. The calendar-time return on this portfolio is used to estimate the following regression:

$$
R_{p t}-R_{f t}=\alpha_{i}+\beta_{i}\left(R_{m t}-R_{f t}\right)+s_{i} S M B_{t}+h_{i} H M L_{t}+\varepsilon_{i t}
$$


where $R_{p t}$ is the simple monthly return on the calendar-time portfolio, $R_{f t}$ is the monthly return on three-month Treasury bills, $R_{m t}$ is the return on a value-weighted market index, $S M B_{t}$ is the difference in the returns of value-weighted portfolios of small stocks and big stocks, and $H M L_{t}$ is the difference in the returns of value-weighted portfolios of high book-to-market stocks and low book-to-market stocks. The estimate of the intercept term $\alpha_{i}$ provides a test of the null hypothesis that the mean monthly excess return of our sample portfolio is zero.

\section{Empirical results}

\subsection{Client firms}

\subsubsection{Client firms' long-run stock performance}

Recent finance research has examined long-run stock performance following firms' major business events. We measure client firms' long-run stock performance after outsourcing contracts taking effect to see whether in the long run, firms benefit from these contracts. The results are reported in table 2 .

\section{[Table 2 here]}

Table 2 shows buy-and-hold returns for client firms and their matching firms in three years after outsourcing contracts. Two specifications of results are reported: size matched, size and book-to-market matched. Panel A contains the whole sample results and the rest panels contain sub-sample results. As shown in both specifications of Panel A, the differences (abnormal returns) between client firms and matching firms are statistically significantly positive at $5 \%$ and $1 \%$ level, respectively. This evidence suggests that on average client firms perform better than their matching firms three years after their contracts taking effect. Several sub-samples also show significant better performance of the client firms compared to their matching firms. Small client firms perform better than their matching firms, whether it is based on sales or MVE. The abnormal returns of Q>1 client firm group (which composes the majority of the whole sample) in Panel $\mathrm{G}$ are significantly positive at $10 \%$ and $5 \%$ levels, respectively; the size and book-to-market matched result of US clients which outsource to US vendors is significantly positive at $1 \%$ level. Table 2 provides evidence that outsourcing is beneficial to client firms in the long run. It gives a possible explanation to the fact that outsourcing becomes a more and more popular phenomenon.

\subsubsection{Client firms' long-run accounting performance}

We also investigate accounting performance of client firms following the initiative of outsourcing contracts. In Table 3 , median changes in accounting performance from one year before to three years after outsourcing effectiveness are reported. Three different measures are reported: unadjusted changes, changes adjusted by subtracting SIC two-digit industry median changes (industry-adjusted), and changes adjusted by subtracting changes for a control group matched by both industry and prior accounting performance (control group-adjusted). The results of whole sample suggest that there are efficiency gains from outsourcing. For all the client firms combined, the median changes in SALEFF and IEFF from year -1 to year 3 are positive and statistically significant with all three different measures. The costs of production are reduced, while the net income is increased ex-post as suggested by the changes in CGSREV and NIREV. Higher asset turnover shows that assets are being deployed more efficiently, as suggested by changes in ASST. Small client firms display a similar pattern. Results of big Q clients and US clients which outsource to US vendors further confirm the efficiency gains experienced by client firms.

[Table 3 here]

The evidence that client firms significantly improve their operating efficiency in three years following their outsourcing contracts, either compared to their industry-medians or a group of control firms, suggests that outsourcing is beneficial to client firms.

\subsubsection{Multivariate results for client firms}

Specifically, we regress the client firms' buy-and-hold abnormal returns, changes in operating performance on measures of firm and contract characteristics. We estimate the following regressions:

$$
\begin{aligned}
& \text { BAH }_{i}=e_{0}+e_{1} \text { CSize }_{i}+e_{2} Q_{i}+e_{3} \text { ForeignV }_{l, i}+\varepsilon_{i} \\
& \Delta \operatorname{SALEFF}_{i}\left(\Delta I E F F_{i}, \Delta C G S R E V_{i}, \Delta N I R E V_{i}, \Delta A S S T_{i}\right)= \\
& e_{4}+e_{5} \text { CSize }_{i}+e_{6} Q_{i}+e_{7} \text { Foreign }_{l, i}+v_{i}
\end{aligned}
$$


where $B A H_{i}$ is client firms' 3-year buy-and-hold abnormal return, $\triangle S A L E F F_{i}\left(\triangle I E F F_{i}, \triangle C G S R E V_{i}, \triangle N I R E V_{i}, \triangle A S S T_{i}\right)$ represents accounting performance changes from year -1 to year +3 . CSize $e_{i}$ is the log of client firm sales or market value of equity at year $-1 . Q_{i}$ is client firm's Tobin's Q. Foreign $V_{l, i}$ is a dummy variable, which equals 1 when US client firm signs a contract with a foreign vendor. For each firm, all the accounting variables are taken from Compustat one year before the contract effective year.

The estimation of Equations (4) and (5) is given in Table 4. In Table 4, client firms' long-run abnormal returns are calculated using size and book-to-market matching-firm adjusted approach. Changes in efficiency are control group-adjusted. The regression results support our univariate results. Client firm size is negatively related to their long-run abnormal returns and the changes of the accounting performance measures, whether size is measured by sales or MVE. Q is positively related to both the stock and accounting performances (Note 10). The dummy variables are not significant (Note 11).

[Table 4 here]

\subsection{Vendor firms}

\subsubsection{Vendor firms' long-run stock performance}

Table 5 shows buy-and-hold returns for vendor firms and their matching firms in three years after outsourcing contracts. Size, size and book-to-market matched results are reported for the whole vendor sample. As shown in both specifications of Table 5, the differences (abnormal returns) between vendor firms and matching firms are statistically insignificant. This evidence is expected because of the way we select our sample to exclude vendors who sign multiple contracts within a 6 year window. We expect the multiple contract winners to perform better than their pairs, while it is impossible to separate the impact of each contract. So the fact that our sample vendor firms do not perform better than control groups is not a surprise.

[Table 5 here]

\subsubsection{Vendor firms' long-run accounting performance}

In a similar vein, our sample vendors do not realize significant improvement of their accounting performance compared to both industry medians and the control group, as reported in Table 6 . It follows the same reason as with their stock performance.

\section{[Table 6 here]}

We do not perform a multivariate regression test for vendor firms. In our third paper, we will discuss in details about those frequent contract winning vendors. So we do not discuss further here about vendor firms.

\section{Robustness of results}

The analysis so far has focused on buy-and-hold abnormal stock returns. As opposed to the event-time approach, the calendar-time approach takes into account the real date of the event. Table 7 reports calendar time three-factor model for client firms. Portfolio formation periods of 12, 24 and 36 months are reported separately. According to the calendar-time results presented, client firms have generated a positive abnormal return in the long-run. Overall, regardless of the horizon, the over-performance estimated by the alpha coefficient is similar to the results obtained via the event-time approach. The results are statistically significant and adjusted $R^{2}$ range from 0.35 (12 months) to 0.56 (36 months).

\section{[Table 7 here]}

Our operating efficiency is proxied by measures including sales efficiency (SALEFF) and income efficiency (IEFF). Both measures are ratios with the same denominator - the number of employees. In order to make sure that our efficiency gains are not caused by layoffs, we perform employee change tests for our client firms. There are no statistically significant changes of the number of employees for our sample clients in three years after outsourcing takes place (Note 12).

Additionally, to show that both the long-run abnormal stock performance and operating efficiency change are not pre-event trend, we report client firms' pre-outsourcing stock performance in Table 8 and their pre-event operating performance in Table 9. Panel A, Table 8 shows that on average, our client firms are actually underperformed compared to a group of firms with similar sizes, the difference is statistically significant at $5 \%$ level. When matched 
both on size and book-to-market ratios, the difference is not statistically significant, nonetheless with a negative sign. Different size groups of client firms under-perform at different levels. Panel $F$ shows that $Q<1$ client firms underperformed their size and book-to-market matched firms by 33\%; Q>1 client firms in Panel G underperformed their size matched firms by $23 \%$. Both results are significant at conventional levels. Results of Table 8 not only confirm that client firms' abnormal stock performance after outsourcing contracts is not a pre-event phenomenon, but also give further evidence that client firms benefit from outsourcing.

[Table 8 here]

Pre-outsourcing accounting performance changes are reported in Table 9. There are no statistically significant patterns of all the efficiency measures before outsourcing takes place. Table 9 provides further evidence to support the robustness of our results.

[Table 9 here]

All in all, our findings appear to be robust with respect to control firm sample selection criteria, alternative definitions of efficiency measures, and the length of the window used to measure operating efficiency changes.

\section{Limitations and future research opportunities}

Based on data limitations, we are unable to address outsourcing deals that happened in most recent years. Further study should be able to re-test our findings using more updated data.

\section{Conclusion}

This paper primarily focuses on testing whether corporate outsourcing contracts are beneficial for outsourcing contract firms in the long run. The long-run ex-post changes in both stock and accounting performance of contract firms are examined.

Our results show that client firms realize statistically significantly positive average buy-and-hold abnormal returns in the long run. We also find consistent evidence that our client firms experience significant improvement of their operating efficiency in three years following the contract effectiveness.

Our findings suggest that outsourcing contracts are beneficial to contract clients in the long run. To our best knowledge, this is the first study to investigate the effectiveness of outsourcing contracts from contract firms' long-run stock and accounting performance perspectives.

\section{References}

Abraham, K. G., Taylor, S. K. (1996). Firms' use of outside contractors: theory and evidence. Journal of Labor Economics 14, 394-424. http://dx.doi.org/10.1086/209816

Adams, J. D., Marcu, M. (2004). R\&D sourcing, joint ventures and innovation: a multiple indicators approach. Working paper.

Barber, B. M., Lyon, J. D. (1996). Detecting abnormal operating performance: the empirical power and specification of test statistics. Journal of Financial Economics 41, 359-399. http://dx.doi.org/10.1016/0304-405X(96)84701-5

Barber, B. M., Lyon, J. D. (1997). Detecting long-run abnormal stock returns: the empirical power and specification of test statistics. Journal of Financial Economics 43, 341-372. http://dx.doi.org/10.1016/S0304-405X(96)00890-2

Bradford M., Pagach., D. (2005). Information conveyed in IS outsourcing announcements. Working paper.

Chaudhury, A., Nam, K., Rao, H. R. (1995). Management of IS outsourcing: a bidding perspective. Journal of Management Information Systems 12, 131-159.

Clarke, R.N. (1989). SICs as delineators of economic markets, Journal of Business 62, 17-31. http://dx.doi.org/10.1086/296449

Coase, R. (1937). The nature of the firm. Economica 4, 386-405. http://dx.doi.org/10.1111/j.1468-0335.1937.tb00002.x

Fama, E. F., French, K. R. (1993). Common risk factors in the returns on stocks and bonds. Journal of Financial Economics 33, 3-56. http://dx.doi.org/10.1016/0304-405X(93)90023-5

Farag, N. I., Krishnan, M. S. (2003). The market value of IT outsourcing investment announcements: an event-study analysis. Ninth Americas Conference on Information Systems.

Fee, C. E., Thomas, S. (2004). Sources of gains in horizontal mergers: evidence from customer, supplier, and rival firms. Journal of Financial Economics 74, 423-460. http://dx.doi.org/10.1016/j.jfineco.2003.10.002 
Gao, N. (2009). "Market Reaction to Corporate Outsourcing Transactions". European Journal of Social Science, 8 (2), 277-296.

Gallivan, M. J., Oh, W. (1999). Analyzing IT outsourcing relationships as alliances among multiple clients and vendors. Proceedings of the 32nd Hawaii International Conference on System Sciences, 1-15.

Gellrich, T., Gewald, H. (2005). Sourcing risk and the capital markets perspective: a study of the global financial services industry. E-FinanceLab working paper.

Girma, S., Gorg, H. (2002). Outsourcing, foreign ownership and productivity: evidence from UK establishment level data. Research paper.

Grossman, S.J., Hart, O. (1986). The Costs and benefits of ownership: a theory of vertical and lateral integration. Journal of Political Economy 94, 691-719. http://dx.doi.org/10.1086/261404

Grossman, G., Helpman, E. (2002). Integration versus outsourcing in industry equilibrium. Quarterly Journal of Economics 117, 85-120. http://dx.doi.org/10.1162/003355302753399454

Hayes, D. C., Hunton, J. E., Reck, J. L. (2000). Information systems outsourcing announcements: investigating the impact on the market value of contract-granting firms. Journal of Information Systems 14, 109-125. http://dx.doi.org/10.2308/jis.2000.14.2.109

Lang, L. H. P., Litzenberger, R. H. (1989). Dividend announcements: cash flow signalling vs. free cash flow hypothesis? Journal of Financial Economics 24, 181-191. http://dx.doi.org/10.1016/0304-405X(89)90077-9

Loughran, T., Ritter, J. R. (1997). The operating performance of firms conducting seasoned equity offerings. The Journal of Finance 52, 1823-1850. http://dx.doi.org/10.1111/j.1540-6261.1997.tb02743.x

McCarthy, I., Anagnostou, A. (2004). The impact of outsourcing on the transaction costs and boundaries of manufacturing. Int. J. Production Economics 88, 61-71. http://dx.doi.org/10.1016/S0925-5273(03)00183-X

Megginson, W.L., Nash. R., Randenborgh, M. V. (1994). The financial and operating performance of newly privatized firms: an international empirical analysis. Journal of Finance 49, 403-452. http://dx.doi.org/10.1111/j.1540-6261.1994.tb05147.x

Quinn, J.B., Hilmer, F.G. (1994). Strategic outsourcing. Sloan Management Review 35, 43-55.

Sharpe, M. (1997). Outsourcing, organizational competitiveness, and work. Journal of Labor Research XVIII, 535-549. http://dx.doi.org/10.1007/s12122-997-1021-8

Williamson, O. (1979). Transaction-cost economics: the governance of contractual relations. Journal of Law and Economics 22, 233-261. http://dx.doi.org/10.1086/466942

Williamson, O. (1985). Assessing Contract. Journal of Law, Economics, \& Organization 1, 177-208.

\section{Notes}

Note 1, Contract values are adjusted for inflation using the Consumer Price Index (CPI) series.

Note 2, The dotted line is the trend line.

Note 3, Source of the citation: Factiva.

Note 4, We also double checked client firms' SEC 10K filings to verify the existence of these events.

Note 5, Compustat data items are used to calculate: $\mathrm{Q}=($ data6 + data25*data199 - data60)/data6.

Note 6, That deal happened in May 2000, the client firm of the contract is Motorola Inc. and the vendor is Flextronics International Ltd. The contract value $\$ 30$ billion is much greater than $\$ 4.04$ billion, the total cash holdings of Motorola Inc in 1999.

Note 7, Compustat data items are used to calculate: SALEFF=data12/data29; IEFF=data13/data29. We deflate these numbers by normalizing year -1 number to unity so other year figures are expressed as a fraction of base year value.

Note 8, Compustat data items are used to calculate: CGSREV=data41/data12; NIREV=data172/data12; ASST $=$ data12/data6.

Note 9, ROA is used to generate more data than other measures.

Note 10, The only exception is CGSREV, which represents costs, so the signs flip with this measure.

Note 11, Repeating the empirical tests with different matching combinations produces qualitatively similar results.

Note 12, The test results will be provided upon individual requests. 
Table 1. Sample description

The sample includes announced outsourcing contracts signed by US publicly listed firms between 1990 and 2003 that are collected from Factiva and also meet the following criteria: Client and vendor firms are US publicly traded firms with sufficient data from the Center for Research in Security Prices (CRSP) to calculate their stock returns. Firms have data available in Compustat on a consolidated basis. All accounting data are obtained from Compustat one year before the contract effective year. All values are reported in 2000 dollars. MVE is market value of equity. Q is Tobin'Q (the ratio of the market value of assets to the replacement cost of assets).

\begin{tabular}{|c|c|c|c|c|c|c|}
\hline Specifications & $\begin{array}{c}\# \\
\text { obs. }\end{array}$ & Mean & Median & Maximum & Minimum & Std. dev. \\
\hline \multicolumn{7}{|c|}{ Panel A: Client firm characteristics } \\
\hline Sales (\$ millions) & 433 & $17,320.52$ & $7,303.08$ & $168,024.84$ & 0.21 & $26,521.39$ \\
\hline MVE (\$ millions) & 421 & $21,483.47$ & $4,919.19$ & $201,435.34$ & 0.08 & $37,945.28$ \\
\hline $\mathrm{Q}$ & 418 & 1.78 & 1.30 & 11.26 & 0.27 & 1.34 \\
\hline \multicolumn{7}{|c|}{ Panel B: Vendor characteristics } \\
\hline Sales (\$ millions) & 828 & $13,439.57$ & $2,189.62$ & $105,809.20$ & 0.03 & $24,878.69$ \\
\hline MVE (\$ millions) & 822 & $20,194.13$ & $2,974.58$ & $353,692.52$ & 0.59 & $47,152.73$ \\
\hline \multicolumn{7}{|c|}{ Panel C: Deal characteristics } \\
\hline Contract years & 471 & 5.88 & 5.00 & 11.00 & 0.50 & 2.61 \\
\hline $\begin{array}{c}\text { Contract value } \\
(\$ \text { millions })\end{array}$ & 575 & 828.59 & 141.00 & $30,000.00$ & 1.15 & $2,359.36$ \\
\hline $\begin{array}{l}\text { Contract value per year } \\
\text { (\$ millions) }\end{array}$ & 471 & 140.27 & 27.89 & $6,000.00$ & 0.50 & 499.52 \\
\hline \multicolumn{7}{|c|}{ Panel D: Deal classifications } \\
\hline & & \# obs. & & & Ratio of total & \\
\hline 1. Deal is a renewal & & 147 & & & $13.73 \%$ & \\
\hline $\begin{array}{l}\text { 2. Governmental deal } \\
\text { (client firm is a } \\
\text { governmental entity) }\end{array}$ & \multicolumn{3}{|c|}{130} & \multicolumn{3}{|c|}{$12.14 \%$} \\
\hline $\begin{array}{l}\text { 3. US client firms } \\
\text { outsource to foreign } \\
\text { vendors }\end{array}$ & \multicolumn{3}{|c|}{21} & \multicolumn{3}{|c|}{$5.71 \%$} \\
\hline $\begin{array}{l}\text { 4. US client firms } \\
\text { outsource to US vendors }\end{array}$ & \multicolumn{3}{|c|}{297} & \multicolumn{3}{|c|}{$80.71 \%$} \\
\hline \multicolumn{7}{|c|}{ Panel E: Client firm industry distribution } \\
\hline $\begin{array}{l}\text { Major outsourcing } \\
\text { industries (SIC code) }\end{array}$ & \multicolumn{3}{|c|}{ Description of industry group } & \multicolumn{3}{|c|}{ Ratio of total } \\
\hline 35 & \multicolumn{3}{|c|}{$\begin{array}{c}\text { Industrial And Commercial } \\
\text { Machinery And Computer } \\
\text { Equipment }\end{array}$} & \multicolumn{3}{|c|}{$11.05 \%$} \\
\hline 73 & \multicolumn{3}{|c|}{ Business Services } & \multicolumn{3}{|c|}{$9.70 \%$} \\
\hline 36 & \multicolumn{3}{|c|}{$\begin{array}{l}\text { Electronic And Other Electrical } \\
\text { Equipment And Components, } \\
\text { Except Computer Equipment }\end{array}$} & \multicolumn{3}{|c|}{$8.36 \%$} \\
\hline 37 & \multicolumn{3}{|c|}{ Transportation Equipment } & \multicolumn{3}{|c|}{$8.36 \%$} \\
\hline \multicolumn{7}{|c|}{ Panel F: Vendor industry distribution } \\
\hline 73 & \multicolumn{3}{|c|}{ Business Services } & \multicolumn{3}{|c|}{$47.41 \%$} \\
\hline 36 & \multicolumn{3}{|c|}{$\begin{array}{l}\text { Electronic And Other Electrical } \\
\text { Equipment And Components, } \\
\text { Except Computer Equipment }\end{array}$} & \multicolumn{3}{|c|}{$7.33 \%$} \\
\hline 35 & \multicolumn{3}{|c|}{$\begin{array}{c}\text { Industrial And Commercial } \\
\text { Machinery And Computer } \\
\text { Equipment }\end{array}$} & \multicolumn{3}{|c|}{$6.03 \%$} \\
\hline 50 & \multicolumn{3}{|c|}{ Wholesale Trade-durable Goods } & \multicolumn{3}{|c|}{$5.60 \%$} \\
\hline
\end{tabular}


Table 2. Ex-post long-run holding period abnormal returns of client firms

Using CRSP daily stock return file, we calculate the buy-and-hold return from the day after outsourcing contract taking effect to three years (756 trading days) after. If a firm is delisted prior to its anniversary date, we truncate its total return on that date. Thus, the percentage buy-and-hold return for firm $i$ is $R_{i T}=\left[\prod_{t=1}^{T}\left(1+r_{i t}\right)-1\right]$. Where

$T$ is the earlier of the last day of CRSP-listed trading or the end of the three-year window, and $r_{i t}$ is the return for firm $i$ on date $t$. Buy-and-hold abnormal returns are defined as the average equally weighted paired differences between buy-and-hold returns of client firms and those of matching firms. The average $\tau$-year abnormal buy-and-hold return is measured as $R_{\tau}=\frac{1}{n} \sum_{i=1}^{n}\left(R_{i T}-R_{m T}\right)$. Where $R_{i T}$ is the percentage buy-and-hold return on firm $i$ for holding period $T . R_{m T}$ is the percentage buy-and-hold return on firm $i$ 's matching firm for holding the same period $T . n$ is the number of client firms in the sample. Panel A reports the whole sample results; the rest of the panels reports sub-sample results according to different classifications. $*, * *, * * *$ denote the statistical significance level of $10 \%, 5 \%$, and $1 \%$, respectively.

\begin{tabular}{|c|c|c|c|c|c|}
\hline Specifications & $\mathrm{N}$ & Client firm & Match & Difference & t-stat \\
\hline \multicolumn{6}{|c|}{ Panel A: All } \\
\hline Size matching & 306 & 0.4184 & 0.2018 & 0.2166 & $2.53^{* *}$ \\
\hline $\begin{array}{c}\text { Size and } \\
\text { book-to-market } \\
\text { matching }\end{array}$ & 299 & 0.4426 & 0.1642 & 0.2784 & $3.18^{* * *}$ \\
\hline \multicolumn{6}{|c|}{ Panel B: Small firms (sales) } \\
\hline Size matching & 153 & 0.5101 & 0.2675 & 0.2426 & $1.76^{*}$ \\
\hline $\begin{array}{c}\text { Size and } \\
\text { book-to-market } \\
\text { matching }\end{array}$ & 150 & 0.5097 & 0.2120 & 0.2977 & $2.39 * *$ \\
\hline \multicolumn{6}{|c|}{ Panel C: Big firms (sales) } \\
\hline Size matching & 153 & 0.4374 & 0.3759 & 0.0615 & 0.58 \\
\hline $\begin{array}{c}\text { Size and } \\
\text { book-to-market } \\
\text { matching }\end{array}$ & 149 & 0.4923 & 0.1871 & 0.3052 & $2.50 * * *$ \\
\hline \multicolumn{6}{|c|}{ Panel D: Small firms (MVE) } \\
\hline Size matching & 153 & 0.5975 & 0.3036 & 0.2938 & $2.12 * *$ \\
\hline $\begin{array}{c}\text { Size and } \\
\text { book-to-market } \\
\text { matching }\end{array}$ & 150 & 0.5854 & 0.2004 & 0.3850 & $3.08^{* * *}$ \\
\hline \multicolumn{6}{|c|}{ Panel E: Big firms (MVE) } \\
\hline Size matching & 153 & 0.3458 & 0.3598 & -0.0140 & -0.15 \\
\hline $\begin{array}{c}\text { Size and } \\
\text { book-to-market } \\
\text { matching }\end{array}$ & 149 & 0.3939 & 0.2318 & 0.1621 & $1.64 *$ \\
\hline \multicolumn{6}{|c|}{ Panel F: $\mathrm{Q}<1$ client firms } \\
\hline Size matching & 52 & 0.3935 & 0.2357 & 0.1578 & 0.96 \\
\hline $\begin{array}{c}\text { Size and } \\
\text { book-to-market } \\
\text { matching }\end{array}$ & 50 & 0.4082 & 0.1957 & 0.2125 & 1.34 \\
\hline \multicolumn{6}{|c|}{ Panel G: $\mathrm{Q}>1$ client firms } \\
\hline Size matching & 254 & 0.4912 & 0.2974 & 0.1938 & $1.92 *$ \\
\hline $\begin{array}{c}\text { Size and } \\
\text { book-to-market } \\
\text { matching }\end{array}$ & 245 & 0.5388 & 0.2688 & 0.2700 & $2.56^{* *}$ \\
\hline
\end{tabular}




\begin{tabular}{|c|c|c|c|c|c|}
\hline \multicolumn{6}{|c|}{ Panel H: US client firms which outsource to foreign vendors } \\
\hline Size matching & 17 & 0.1451 & 0.0499 & 0.0952 & 0.98 \\
\hline $\begin{array}{c}\text { Size and } \\
\text { book-to-market } \\
\text { matching }\end{array}$ & 17 & 0.1134 & 0.0584 & 0.0550 & 0.31 \\
\hline \multicolumn{7}{|c|}{ Panel I: US client firms which outsource to US vendors } \\
\hline Size matching & 250 & 0.5653 & 0.4090 & 0.1563 & 1.46 \\
\hline $\begin{array}{c}\text { Size and } \\
\text { book-to-market } \\
\text { matching }\end{array}$ & 249 & 0.5813 & 0.2595 & 0.3218 & $3.39^{* * *}$ \\
\hline
\end{tabular}

Table 3. Ex-post accounting performance changes of client firms

Median changes in accounting performance from one year before to three years after outsourcing effectiveness are calculated. Three different measures are reported: unadjusted changes, changes adjusted by subtracting SIC two-digit industry median changes (industry-adjusted), and changes adjusted by subtracting changes for a control group matched by both industry and prior accounting performance (control group-adjusted). SALEFF is sales efficiency; IEFF is income efficiency; CGSREV is costs of goods sold divided by sales; NIREV is net income divided by sales; and ASST is asset turnover. Sample sizes and median sign-test statistics are reported in parentheses. *, **, *** denote statistical significance at the $10 \%, 5 \%$, and $1 \%$ level, respectively.

\begin{tabular}{|c|c|c|c|c|c|}
\hline Specifications & All & $\begin{array}{c}\text { Small firm } \\
\text { (sales) }\end{array}$ & $\begin{array}{c}\text { Big firm } \\
\text { (sales) }\end{array}$ & $\begin{array}{c}\text { Small firm } \\
\text { (MVE) }\end{array}$ & $\begin{array}{c}\text { Big firms } \\
\text { ( MVE) }\end{array}$ \\
\hline \multicolumn{6}{|c|}{ Panel A: Changes in SALEFF } \\
\hline Unadjusted & $\begin{array}{c}0.19349 \\
(254,50.0)^{* * *}\end{array}$ & $\begin{array}{c}0.18915 \\
(127,23.0)^{* * *}\end{array}$ & $\begin{array}{c}0.19682 \\
(127,27.0)^{* * *}\end{array}$ & $\begin{array}{c}0.16022 \\
(127,23.5)^{* * *}\end{array}$ & $\begin{array}{c}0.22660 \\
(127,26.5)^{* * *}\end{array}$ \\
\hline $\begin{array}{c}\text { Industry } \\
\text { median-adjusted }\end{array}$ & $\begin{array}{c}0.08173 \\
(254,13.0)^{* *}\end{array}$ & $\begin{array}{c}0.10819 \\
(127,15.0)^{* *}\end{array}$ & $\begin{array}{c}0.09010 \\
(127,10.0)^{*}\end{array}$ & $\begin{array}{c}0.10997 \\
(127,12.0)^{* *}\end{array}$ & $\begin{array}{c}0.09628 \\
(127,10.0)^{*}\end{array}$ \\
\hline $\begin{array}{c}\text { Control } \\
\text { group-adjusted }\end{array}$ & $\begin{array}{c}0.08275 \\
(251,13.5)^{* *}\end{array}$ & $\begin{array}{c}0.08550 \\
(126,10.5)^{*}\end{array}$ & $\begin{array}{c}-0.00609 \\
(125,-3.0)\end{array}$ & $\begin{array}{c}0.08275 \\
(126,9.5)^{*}\end{array}$ & $\begin{array}{c}0.05270 \\
(125,8.0)\end{array}$ \\
\hline \multicolumn{6}{|c|}{ Panel B: Changes in IEFF } \\
\hline Unadjusted & $\begin{array}{c}0.24062(251 \\
24.5)^{* * *}\end{array}$ & $\begin{array}{c}0.21340 \\
(126,14.5)^{* *}\end{array}$ & $\begin{array}{c}0.25407 \\
(125,25.0)^{* * *}\end{array}$ & $\begin{array}{c}0.26615 \\
(126,22.0)^{* * *}\end{array}$ & $\begin{array}{c}0.23070 \\
(125,19.5)^{* * *}\end{array}$ \\
\hline $\begin{array}{c}\text { Industry } \\
\text { median-adjusted }\end{array}$ & $\begin{array}{c}0.06822 \\
(251,15.5)^{* *} \\
\end{array}$ & $\begin{array}{r}0.08230 \\
(126,5.5) \\
\end{array}$ & $\begin{array}{c}0.02730 \\
(125,4.0) \\
\end{array}$ & $\begin{array}{c}0.05364 \\
(126,15.0)^{* *} \\
\end{array}$ & $\begin{array}{c}0.07821 \\
(125,12.0)^{* *} \\
\end{array}$ \\
\hline $\begin{array}{c}\text { Control } \\
\text { group-adjusted }\end{array}$ & $\begin{array}{c}0.05542 \\
(249,13.5)^{* *}\end{array}$ & $\begin{array}{c}0.07212 \\
(125,9.5)^{*}\end{array}$ & $\begin{array}{c}-0.01261 \\
(124,-1.0) \\
\end{array}$ & $\begin{array}{c}0.05591 \\
(125,10.5)^{*}\end{array}$ & $\begin{array}{c}0.04373 \\
(124,6.0) \\
\end{array}$ \\
\hline \multicolumn{6}{|c|}{ Panel C: Changes in CGSREV } \\
\hline Unadjusted & $\begin{array}{c}-0.00271 \\
(251,-2.0)\end{array}$ & $\begin{array}{c}0.00449 \\
(126,3.5)\end{array}$ & $\begin{array}{c}-0.00709 \\
(125,-1.5)\end{array}$ & $\begin{array}{c}0.00444 \\
(126,3.0)\end{array}$ & $\begin{array}{c}-0.00676 \\
(125,-2.0)\end{array}$ \\
\hline $\begin{array}{c}\text { Industry } \\
\text { median-adjusted }\end{array}$ & $\begin{array}{c}-0.01285 \\
(251,-13.5)^{*}\end{array}$ & $\begin{array}{c}-0.02012 \\
(126,-16.0)^{* *}\end{array}$ & $\begin{array}{c}0.00200 \\
(125,0.5) \\
\end{array}$ & $\begin{array}{c}-0.01447 \\
(126,-9.5)^{*}\end{array}$ & $\begin{array}{c}0.00831 \\
(125,4.0) \\
\end{array}$ \\
\hline $\begin{array}{c}\text { Control } \\
\text { group-adjusted }\end{array}$ & $\begin{array}{c}-0.00522 \\
(249,-12.5)^{*}\end{array}$ & $\begin{array}{c}-0.00580 \\
(125,-14.5)^{* *}\end{array}$ & $\begin{array}{c}0.00019 \\
(124,6.5)\end{array}$ & $\begin{array}{c}-0.00679 \\
(125,-10.5)^{*}\end{array}$ & $\begin{array}{c}0.00377 \\
(124,6.0) \\
\end{array}$ \\
\hline \multicolumn{6}{|c|}{ Panel D: Changes in NIREV } \\
\hline Unadjusted & $\begin{array}{c}0.02251 \\
(251,15.0)^{* *}\end{array}$ & $\begin{array}{c}0.02025 \\
(126,14.5)^{* *}\end{array}$ & $\begin{array}{c}0.02372 \\
(125,10.5)^{*}\end{array}$ & $\begin{array}{c}0.01438 \\
(126,12.5)^{* *}\end{array}$ & $\begin{array}{c}0.02842 \\
(125,10.0)^{*}\end{array}$ \\
\hline $\begin{array}{c}\text { Industry } \\
\text { median-adjusted }\end{array}$ & $\begin{array}{c}0.01589 \\
(251,13.0)^{*} \\
\end{array}$ & $\begin{array}{c}0.02841 \\
(126,9.5)^{*} \\
\end{array}$ & $\begin{array}{c}0.01993 \\
(125,3.5) \\
\end{array}$ & $\begin{array}{c}0.01022 \\
(126,10.0)^{*}\end{array}$ & $\begin{array}{c}0.01766 \\
(125,6.0) \\
\end{array}$ \\
\hline $\begin{array}{c}\text { Control } \\
\text { group-adjusted }\end{array}$ & $\begin{array}{c}0.00898 \\
(249,13.0)^{*}\end{array}$ & $\begin{array}{c}0.01702 \\
(125,10.0)^{*}\end{array}$ & $\begin{array}{c}0.00903 \\
(124,5.5)\end{array}$ & $\begin{array}{c}0.00937 \\
(125,9.5)^{*}\end{array}$ & $\begin{array}{c}0.01154 \\
(124,6.5)\end{array}$ \\
\hline \multicolumn{6}{|c|}{ Panel E: Changes in ASST } \\
\hline Unadjusted & $\begin{array}{c}0.01216 \\
(254,8.0)\end{array}$ & $\begin{array}{c}0.01281 \\
(127,4.5)\end{array}$ & $\begin{array}{c}0.01533 \\
(127,5.5)\end{array}$ & $\begin{array}{c}0.02287 \\
(127,7.0)\end{array}$ & $\begin{array}{c}0.01170 \\
(127,3.0)\end{array}$ \\
\hline $\begin{array}{c}\text { Industry } \\
\text { median-adjusted }\end{array}$ & $\begin{array}{c}0.02578 \\
(254,21.5)^{* * *}\end{array}$ & $\begin{array}{c}0.02924 \\
(127,15.0)^{* *}\end{array}$ & $\begin{array}{c}0.02186 \\
(127,10.5)^{*}\end{array}$ & $\begin{array}{c}0.02643 \\
(127,12.0)^{*}\end{array}$ & $\begin{array}{c}0.01872 \\
(127,6.0)\end{array}$ \\
\hline
\end{tabular}




\begin{tabular}{|c|c|c|c|c|c|}
\hline $\begin{array}{c}\text { Control } \\
\text { group-adjusted }\end{array}$ & 0.00541 & 0.01522 & -0.01356 & 0.01719 & -0.01356 \\
$(252,12.0)^{*}$ & $(126,3.0)$ & $(126,-1.5)$ & $(126,10.5)^{*}$ & $(126,-2.5)$ \\
\hline
\end{tabular}

\begin{tabular}{|c|c|c|c|c|}
\hline Specifications & $\mathrm{Q}<1$ & $\mathrm{Q}>1$ & To foreign vendor & To US vendor \\
\hline \multicolumn{5}{|c|}{ Panel A: Changes in SALEFF } \\
\hline Unadjusted & $\begin{array}{c}0.13822 \\
(29,4.5)^{*}\end{array}$ & $\begin{array}{c}0.19727 \\
(225,44.5)^{* * *}\end{array}$ & $\begin{array}{l}0.16169 \\
(13,1.5)\end{array}$ & $\begin{array}{c}0.18955 \\
(231,33.5)^{* * *}\end{array}$ \\
\hline $\begin{array}{c}\text { Industry } \\
\text { median-adjusted }\end{array}$ & $\begin{array}{l}-0.04158 \\
(29,-1.5) \\
\end{array}$ & $\begin{array}{c}0.09832 \\
(225,22.0)^{* * *} \\
\end{array}$ & $\begin{array}{l}0.02913 \\
(13,0.5) \\
\end{array}$ & $\begin{array}{c}0.09449 \\
(231,9.5)^{*} \\
\end{array}$ \\
\hline $\begin{array}{c}\text { Control } \\
\text { group-adjusted }\end{array}$ & $\begin{array}{l}0.06159 \\
(28,0.5) \\
\end{array}$ & $\begin{array}{c}0.04275 \\
(222,12.5)^{* *}\end{array}$ & $\begin{array}{l}-0.02038 \\
(11,-1.5) \\
\end{array}$ & $\begin{array}{c}0.05191 \\
(230,11.0)^{* *}\end{array}$ \\
\hline \multicolumn{5}{|c|}{ Panel B: Changes in IEFF } \\
\hline Unadjusted & $\begin{array}{l}0.10310 \\
(28,3.0) \\
\end{array}$ & $\begin{array}{c}0.25340 \\
(223,20.5)^{* * *}\end{array}$ & $\begin{array}{l}0.07675 \\
(13,0.5) \\
\end{array}$ & $\begin{array}{c}0.23070 \\
(230,12.5)^{* * *}\end{array}$ \\
\hline $\begin{array}{c}\text { Industry } \\
\text { median-adjusted }\end{array}$ & $\begin{array}{l}0.00669 \\
(28,0.5)\end{array}$ & $\begin{array}{c}0.07327 \\
(223,15.0)^{* * *}\end{array}$ & $\begin{array}{l}0.01510 \\
(13,0.5)\end{array}$ & $\begin{array}{c}0.13199 \\
(230,10.5)^{* *}\end{array}$ \\
\hline $\begin{array}{c}\text { Control } \\
\text { group-adjusted }\end{array}$ & $\begin{array}{l}0.04180 \\
(28,1.0)\end{array}$ & $\begin{array}{c}0.04982 \\
(221,12.0)^{* *}\end{array}$ & $\begin{array}{l}-0.01262 \\
(11,-0.5)\end{array}$ & $\begin{array}{c}0.05591 \\
(228,11.5)^{* *}\end{array}$ \\
\hline \multicolumn{5}{|c|}{ Panel C: Changes in CGSREV } \\
\hline Unadjusted & $\begin{array}{l}0.00605 \\
(27,2.5) \\
\end{array}$ & $\begin{array}{c}-0.00165 \\
(222,-0.5) \\
\end{array}$ & $\begin{array}{l}0.01210 \\
(13,1.5) \\
\end{array}$ & $\begin{array}{c}-0.00344 \\
(227,-1.5) \\
\end{array}$ \\
\hline $\begin{array}{c}\text { Industry } \\
\text { median-adjusted }\end{array}$ & $\begin{array}{l}0.00683 \\
(27,2.5) \\
\end{array}$ & $\begin{array}{c}-0.00983 \\
(222,-12.0)^{* *}\end{array}$ & $\begin{array}{l}0.01959 \\
(13,0.5)\end{array}$ & $\begin{array}{c}-0.00821 \\
(227,-2.5) \\
\end{array}$ \\
\hline $\begin{array}{c}\text { Control } \\
\text { group-adjusted }\end{array}$ & $\begin{array}{l}0.00495 \\
(27,1.5) \\
\end{array}$ & $\begin{array}{c}-0.00425 \\
(221,-10.0)^{*}\end{array}$ & $\begin{array}{l}-0.00800 \\
(13,-1.0)\end{array}$ & $\begin{array}{c}-0.00451 \\
(226,-11.5)^{*}\end{array}$ \\
\hline \multicolumn{5}{|c|}{ Panel D: Changes in NIREV } \\
\hline Unadjusted & $\begin{array}{l}-0.02338 \\
(27,-3.5)\end{array}$ & $\begin{array}{c}0.02090 \\
(222,0.0) \\
\end{array}$ & $\begin{array}{l}0.02659 \\
(13,0.5)\end{array}$ & $\begin{array}{c}-0.02026 \\
(227,-0.5)\end{array}$ \\
\hline $\begin{array}{c}\text { Industry } \\
\text { median-adjusted }\end{array}$ & $\begin{array}{l}-0.01773 \\
(27,-4.5) \\
\end{array}$ & $\begin{array}{c}0.01476 \\
(222,10.0)^{*}\end{array}$ & $\begin{array}{l}0.02680 \\
(13,0.5) \\
\end{array}$ & $\begin{array}{r}0.01009 \\
(227,4.5)\end{array}$ \\
\hline $\begin{array}{c}\text { Control } \\
\text { group-adjusted }\end{array}$ & $\begin{array}{l}-0.02136 \\
(27,-3.0) \\
\end{array}$ & $\begin{array}{c}0.00500 \\
(221,5.0) \\
\end{array}$ & $\begin{array}{l}0.03616 \\
(13,1.5) \\
\end{array}$ & $\begin{array}{c}0.00837 \\
(226,11.0)^{*}\end{array}$ \\
\hline \multicolumn{5}{|c|}{ Panel E: Changes in ASST } \\
\hline Unadjusted & $\begin{array}{l}0.05755 \\
(27,2.5) \\
\end{array}$ & $\begin{array}{c}0.02032 \\
(224,12.0)^{* *}\end{array}$ & $\begin{array}{l}-0.09605 \\
(13,-1.5)\end{array}$ & $\begin{array}{c}-0.01021 \\
(225,-3.5) \\
\end{array}$ \\
\hline $\begin{array}{c}\text { Industry } \\
\text { median-adjusted }\end{array}$ & $\begin{array}{c}0.03456 \\
(27,8.0)^{* * *}\end{array}$ & $\begin{array}{c}0.02302 \\
(224,15.0)^{* *}\end{array}$ & $\begin{array}{l}0.07534 \\
(13,1.5)\end{array}$ & $\begin{array}{c}0.03157 \\
(225,17.0)^{* * *}\end{array}$ \\
\hline $\begin{array}{c}\text { Control } \\
\text { group-adjusted }\end{array}$ & $\begin{array}{c}0.07634 \\
(27,7.5)^{* *}\end{array}$ & $\begin{array}{c}0.00685 \\
(223,7.0)\end{array}$ & $\begin{array}{l}0.00236 \\
(13,0.5)\end{array}$ & $\begin{array}{c}0.00487 \\
(223,12.5)^{*}\end{array}$ \\
\hline
\end{tabular}


Table 4. Regressions of client firms' long-run abnormal stock returns and accounting performance changes Client firms' long-run abnormal returns are calculated using size and book-to-market matching-firm adjusted approach. Changes in accounting measures are control group-adjusted. We estimate the following regressions,

$$
B A H_{i}=e_{0}+e_{1} \text { CSize }_{i}+e_{2} Q_{i}+e_{3} \text { Foreign }_{l, i}+\varepsilon_{i}
$$

$\triangle \operatorname{SALEFF}_{i}\left(\triangle \mathrm{IEFF}_{i}, \Delta \mathrm{CGSREV}_{i}, \Delta N I R E V_{i}, \Delta A S S T_{i}\right)=e_{4}+e_{5}$ CSize $_{i}+e_{6} Q_{i}+e_{7}$ Foreign $_{l, i}+v_{i}$

where $B A H_{i}$ is client firms' 3-year buy-and-hold abnormal return, $\triangle \operatorname{SALEFF}_{i}\left(\triangle I E F F_{i}, \Delta C G S R E V_{i}, \triangle N I R E V_{i}, \triangle A S S T_{i}\right)$ represents accounting performance changes from year -1 to year +3 . CSize ${ }_{i}$ is the log of client firm sales or market value of equity at year -1 . $Q_{i}$ is client firm's Tobin's Q. Foreign $V_{l, i}$ is a dummy variable, which equals 1 when US client firm signs a contract with a foreign vendor. t-statistics are reported in parentheses. *, **, *** denote statistical significance at 10\%, 5\%, and 1\% level, respectively.

\begin{tabular}{|c|c|c|c|c|c|c|}
\hline $\begin{array}{c}\text { Dependent } \\
\text { variable }\end{array}$ & BAH & $\Delta$ SALEFF & $\Delta$ IEFF & $\begin{array}{c}\Delta \\
\text { CGSREV }\end{array}$ & $\Delta$ NIREV & $\Delta$ ASST \\
\hline Observations & 241 & 243 & 239 & 239 & 239 & 243 \\
\hline \multirow{2}{*}{ Constant } & -0.9580 & 0.8223 & 1.0031 & 0.0804 & -0.3181 & 0.3421 \\
& $(-1.54)$ & $(1.34)$ & $(1.61)$ & $(0.62)$ & $(-1.45)$ & $(2.28)^{* *}$ \\
\hline \multirow{2}{*}{ Sales } & -0.0921 & & -0.0939 & & -0.0449 & \\
& $(-1.78)^{*}$ & & $(-1.82)^{*}$ & & $(-1.80)^{*}$ & \\
\hline \multirow{2}{*}{ MVE } & & -0.0917 & & 0.0106 & & -0.0313 \\
& & $(-1.76)^{*}$ & & $(2.10)^{* *}$ & & $(-1.84)^{*}$ \\
\hline \multirow{2}{*}{$\mathrm{Q}$} & 0.4475 & 0.1872 & 0.1610 & -0.0211 & 0.0548 & 0.0137 \\
& $(3.94)^{* * *}$ & $(1.85)^{*}$ & $(1.98)^{* *}$ & $(-2.20)^{* *}$ & $(1.64)^{*}$ & $(0.59)$ \\
\hline \multirow{2}{*}{ US to foreign } & -0.6145 & -1.1058 & -0.9633 & -0.0095 & -0.0762 & 0.1695 \\
& $(-0.66)$ & $(-1.05)$ & $(-1.46)$ & $(-0.05)$ & $(-0.26)$ & $(0.85)$ \\
\hline Adjusted $R^{2}$ & 0.0952 & 0.0773 & 0.0620 & 0.0697 & 0.0859 & 0.0452 \\
\hline
\end{tabular}

Table 5. Ex-post long-run holding period abnormal returns of vendor firms

Using CRSP daily stock return file, we calculate the buy-and-hold return from the day after outsourcing contract taking effect to three years (756 trading days) after. If a firm is delisted prior to its anniversary date, we truncate its total return on that date. Thus, the percentage buy-and-hold return for firm $i$ is $R_{i T}=\left[\prod_{t=1}^{T}\left(1+r_{i t}\right)-1\right]$. Where $T$ is the earlier of the last day of CRSP-listed trading or the end of the three-year window, and $r_{i t}$ is the return for firm $i$ on date $t$. Buy-and-hold abnormal returns are defined as the average equally weighted paired differences between buy-and-hold returns of vendor firms and those of matching firms. The average $\tau$-year abnormal buy-and-hold return is measured as $R_{\tau}=\frac{1}{n} \sum_{i=1}^{n}\left(R_{i T}-R_{m T}\right)$. Where $R_{i T}$ is the percentage buy-and-hold return on firm $i$ for holding period $T . R_{m T}$ is the percentage buy-and-hold return on firm $i$ 's matching firm for holding the same period $T . n$ is the number of vendor firms in the sample. To be precise, the 3-year holding period for firm $i$ is the minimum of either 3 years or the portion of this time during which it is listed on the CRSP tapes. $* * *, * * *$ denote the statistical significance level of $10 \%, 5 \%$, and $1 \%$, respectively.

\begin{tabular}{|c|c|c|c|c|c|}
\hline Specifications & $\mathrm{N}$ & Vendor firm & Match & Difference & $\mathrm{t}$-stat \\
\hline Size matching & 215 & 0.2126 & 0.3040 & -0.0914 & -0.94 \\
\hline $\begin{array}{c}\text { Size and book-to-market } \\
\text { matching }\end{array}$ & 215 & 0.1616 & 0.3459 & -0.1843 & -1.31 \\
\hline
\end{tabular}


Table 6. Ex-post accounting performance changes of vendor firms

Median changes in accounting performance from one year before to three years after outsourcing effectiveness are calculated. Three different measures are reported: unadjusted changes, changes adjusted by subtracting SIC two-digit industry median changes (industry-adjusted), and changes adjusted by subtracting changes for a control group matched by both industry and prior accounting performance (control group-adjusted). SALEFF is sales efficiency; IEFF is income efficiency; CGSREV is costs of goods sold divided by revenue; NIREV is net income divided by revenue; and ASST is asset turnover. Sample sizes and median sign-test statistics are reported in parentheses. *, **, *** denote statistical significance at the $10 \%, 5 \%$, and $1 \%$ level, respectively.

\begin{tabular}{|c|c|c|c|}
\hline Specifications & Unadjusted changes & $\begin{array}{c}\text { Industry median- } \\
\text { adjusted changes }\end{array}$ & $\begin{array}{c}\text { Control group- adjusted } \\
\text { changes }\end{array}$ \\
\hline \multirow{2}{*}{ SALEFF } & 0.18993 & -0.11012 & -0.03403 \\
& $(216,20.0)^{* * *}$ & $(216,-4.0)$ & $(216,-3.0)$ \\
\hline \multirow{2}{*}{ IEFF } & 0.10090 & 0.06801 & -0.03081 \\
& $(215,13.5)^{*}$ & $(215,16.0)^{* *}$ & $(215,-8.5)$ \\
\hline CGSREV & -0.01936 & 0.00533 & -0.02569 \\
& $(215,-17.5)^{* *}$ & $(215,7.5)$ & $(215,-12.5)^{*}$ \\
\hline NIREV & 0.01710 & 0.01991 & -0.00686 \\
& $(214,17.5)^{* *}$ & $(214,8.5)$ & $(214,-4.5)$ \\
\hline ASST & 0.06324 & 0.09196 & -0.02425 \\
& $(214,1.5)$ & $(214,14.5)^{* *}$ & $(214,-3.5)$ \\
\hline
\end{tabular}

Table 7. Calendar time three-factor model for client firms

The calendar-time period starts in 1990 and ends on the last day of CRSP listing when the 36-month post-event window is considered. For each calendar month, we calculate the return on a portfolio composed of firms that has an event within our calendar window. The calendar-time return on this portfolio is used to estimate the following regression:

$$
R_{p t}-R_{f t}=\alpha_{i}+\beta_{i}\left(R_{m t}-R_{f t}\right)+s_{i} S M B_{t}+h_{i} H M L_{t}+\varepsilon_{i t}
$$

where $R_{p t}$ is the simple monthly return on the calendar-time portfolio, $R_{f t}$ is the monthly return on three-month Treasury bills, $R_{m t}$ is the return on a value-weighted market index, $S M B_{t}$ is the difference in the returns of value-weighted portfolios of small stocks and big stocks, and $H M L_{t}$ is the difference in the returns of value-weighted portfolios of high book-to-market stocks and low book-to-market stocks. The estimate of the intercept term $\alpha_{i}$ provides a test of the null hypothesis that the mean monthly excess return of our sample is zero. t-statistics are reported in parentheses. $*, * *, * *$ denote statistical significance at $10 \%, 5 \%$, and $1 \%$ level, respectively.

\begin{tabular}{|c|c|c|c|c|c|}
\hline Specifications & $\alpha$ & $M K T$ & $S M B$ & $H M L$ & Adjusted $R^{2}$ \\
\hline 12 months & $\begin{array}{l}0.12331 \\
(2.45)^{* *}\end{array}$ & $\begin{array}{l}0.73452 \\
(2.43)^{* *}\end{array}$ & $\begin{array}{c}0.37345 \\
(3.35)^{* * *}\end{array}$ & $\begin{array}{l}0.19123 \\
(1.76)^{*}\end{array}$ & 0.35 \\
\hline 24 months & $\begin{array}{c}0.21604 \\
(3.67)^{* * *}\end{array}$ & $\begin{array}{l}0.67127 \\
(2.28)^{* *}\end{array}$ & $\begin{array}{c}0.31452 \\
(3.24)^{* * *}\end{array}$ & $\begin{array}{l}0.15077 \\
(2.08)^{* *}\end{array}$ & 0.51 \\
\hline 36 months & $\begin{array}{c}0.28104 \\
(3.46)^{* * *}\end{array}$ & $\begin{array}{l}0.67011 \\
(2.25)^{* *}\end{array}$ & $\begin{array}{c}0.37927 \\
(3.30)^{* * *}\end{array}$ & $\begin{array}{c}0.22182 \\
(2.85)^{* * *}\end{array}$ & 0.56 \\
\hline
\end{tabular}


Table 8. Ex-anti holding-period abnormal returns of client firms

Using CRSP daily stock return file, we calculate the buy-and-hold return from three years (756 trading days) before to one day before outsourcing contract effectiveness. The percentage buy-and-hold return for firm $i$ is $R_{i T}=\left[\prod_{t=\min [3 \text { YearsBefore,listed }]}^{t=-1}\left(1+r_{i t}\right)-1\right]$. Where $r_{i t}$ is the return for firm $i$ on date $t$. Buy-and-hold abnormal returns are defined as the average equally weighted paired differences between buy-and-hold returns of client firms and those of matching firms. The average $\tau$-year abnormal buy-and-hold return is measured as $R_{\tau}=\frac{1}{n} \sum_{i=1}^{n}\left(R_{i T}-R_{m T}\right)$. Where $R_{i T}$ is the percentage buy-and-hold return on firm $i$ for holding period $T . R_{m T}$ is the percentage buy-and-hold return on firm $i$ 's matching firm for holding the same period $T . n$ is the number of client firms in the sample. To be precise, the 3-year holding period for firm $i$ is the minimum of either 3 years or the portion of this time during which it is listed on the CRSP tapes. Panel A reports the whole sample results; the rest of the panels reports sub-sample results. ${ }^{*}, * *, * * *$ denote the statistical significance level of $10 \%, 5 \%$, and $1 \%$, respectively.

\begin{tabular}{|c|c|c|c|c|c|}
\hline Specifications & $\mathrm{N}$ & Client firm & Match & Difference & t-stat \\
\hline \multicolumn{6}{|c|}{ Panel A: All } \\
\hline Size matching & 287 & 0.3665 & 0.6342 & -0.2677 & $-2.14 * *$ \\
\hline $\begin{array}{c}\text { Size and } \\
\text { book-to-market } \\
\text { matching }\end{array}$ & 257 & 0.3675 & 0.4411 & -0.0736 & -0.78 \\
\hline \multicolumn{6}{|c|}{ Panel B: Small firms (sales) } \\
\hline Size matching & 144 & 0.3194 & 0.5729 & -0.2535 & $-1.78 *$ \\
\hline $\begin{array}{c}\text { Size and } \\
\text { book-to-market } \\
\text { matching }\end{array}$ & 129 & 0.2899 & 0.3685 & -0.0786 & -0.69 \\
\hline \multicolumn{6}{|c|}{ Panel C: Big firms (sales) } \\
\hline Size matching & 143 & 0.4135 & 0.8020 & -0.3885 & $-1.72 *$ \\
\hline $\begin{array}{c}\text { Size and } \\
\text { book-to-market } \\
\text { matching }\end{array}$ & 128 & 0.4963 & 0.3983 & 0.0980 & 0.86 \\
\hline \multicolumn{6}{|c|}{ Panel D: Small firms (MVE) } \\
\hline Size matching & 144 & 0.2303 & 0.4688 & -0.2385 & $-1.90 *$ \\
\hline $\begin{array}{c}\text { Size and } \\
\text { book-to-market } \\
\text { matching }\end{array}$ & 129 & 0.2264 & 0.3960 & -0.1696 & $-1.72 *$ \\
\hline \multicolumn{6}{|c|}{ Panel E: Big firms (MVE) } \\
\hline Size matching & 143 & 0.5635 & 0.6505 & -0.0870 & -0.66 \\
\hline $\begin{array}{c}\text { Size and } \\
\text { book-to-market } \\
\text { matching }\end{array}$ & 128 & 0.6586 & 0.3648 & 0.2938 & $2.29 * *$ \\
\hline \multicolumn{6}{|c|}{ Panel F: $\mathrm{Q}<1$ client firms } \\
\hline Size matching & 41 & -0.0136 & 0.9230 & -0.9366 & -1.53 \\
\hline $\begin{array}{c}\text { Size and } \\
\text { book-to-market } \\
\text { matching }\end{array}$ & 39 & -0.1050 & 0.2258 & -0.3308 & $-2.24 * *$ \\
\hline \multicolumn{6}{|c|}{ Panel G: $\mathrm{Q}>1$ client firms } \\
\hline Size matching & 244 & 0.3434 & 0.5827 & -0.2393 & $-1.66^{*}$ \\
\hline $\begin{array}{c}\text { Size and } \\
\text { book-to-market } \\
\text { matching }\end{array}$ & 214 & 0.5288 & 0.6492 & -0.1204 & -0.84 \\
\hline
\end{tabular}




\begin{tabular}{|c|c|c|c|c|c|}
\hline \multicolumn{6}{|c|}{ Panel H: US client firms which outsource to foreign vendors } \\
\hline Size matching & 17 & 0.1086 & 0.3359 & -0.2273 & -1.10 \\
\hline $\begin{array}{c}\text { Size and } \\
\text { book-to-market } \\
\text { matching }\end{array}$ & 17 & 0.2027 & 0.4952 & -0.2925 & -1.24 \\
\hline \multicolumn{7}{|c|}{ Panel I: US client firms which outsource to US vendors } \\
\hline Size matching & 247 & 0.4177 & 0.5335 & -0.1159 & -1.03 \\
\hline $\begin{array}{c}\text { Size and } \\
\text { book-to-market } \\
\text { matching }\end{array}$ & 246 & 0.4346 & 0.4087 & 0.0260 & 0.23 \\
\hline
\end{tabular}

Table 9. Ex-anti accounting performance changes of client firms

Median changes in accounting performance from three years before to one year before outsourcing effectiveness are calculated. Three different measures are reported: unadjusted changes, changes adjusted by subtracting SIC two-digit industry median changes (industry-adjusted), and changes adjusted by subtracting changes for a control group matched by both industry and prior accounting performance (control group-adjusted). SALEFF is sales efficiency; IEFF is income efficiency; CGSREV is costs of goods sold divided by revenue; NIREV is net income divided by revenue; and ASST is asset turnover. Sample sizes and median sign-test statistics are reported in parentheses. *, **, *** denote statistical significance at the $10 \%, 5 \%$, and $1 \%$ level, respectively.

\begin{tabular}{|c|c|c|c|c|c|}
\hline Specifications & All & $\begin{array}{c}\text { Small firm } \\
\text { (sales) }\end{array}$ & $\begin{array}{c}\text { Big firm } \\
\text { (sales) }\end{array}$ & $\begin{array}{l}\text { Small firm } \\
\text { (MVE) }\end{array}$ & $\begin{array}{l}\text { Big firms } \\
\text { ( MVE) }\end{array}$ \\
\hline \multicolumn{6}{|c|}{ Panel A: Changes in SALEFF } \\
\hline Unadjusted & $\begin{array}{c}0.13142(278, \\
11.5)\end{array}$ & $\begin{array}{c}0.12635 \\
(139,10.0)^{*}\end{array}$ & $\begin{array}{c}0.14283 \\
(139,13.0)^{*}\end{array}$ & $\begin{array}{c}0.11467 \\
(139,12.5)^{*}\end{array}$ & $\begin{array}{c}0.15058 \\
(139,11.0)^{*}\end{array}$ \\
\hline $\begin{array}{c}\text { Industry } \\
\text { median-adjusted }\end{array}$ & $\begin{array}{c}-0.01670 \\
(278,-3.0) \\
\end{array}$ & $\begin{array}{c}0.09820 \\
(139,7.0)\end{array}$ & $\begin{array}{c}0.09628 \\
(139,9.0)^{*}\end{array}$ & $\begin{array}{c}-0.06450 \\
(139,-8.5)\end{array}$ & $\begin{array}{c}0.07522 \\
(139,6.5)\end{array}$ \\
\hline $\begin{array}{c}\text { Control } \\
\text { group-adjusted } \\
\end{array}$ & $\begin{array}{c}-0.06720 \\
(278,-11.0)\end{array}$ & $\begin{array}{c}-0.05360 \\
(139,-7.5) \\
\end{array}$ & $\begin{array}{c}-0.02045 \\
(139,-2.0) \\
\end{array}$ & $\begin{array}{c}-0.05320 \\
(139,-9.0) \\
\end{array}$ & $\begin{array}{c}0.01857 \\
(139,0.0) \\
\end{array}$ \\
\hline \multicolumn{6}{|c|}{ Panel B: Changes in IEFF } \\
\hline Unadjusted & $\begin{array}{r}0.11997 \\
(278,-9.5)\end{array}$ & $\begin{array}{c}0.12130 \\
(139,12.5)^{*}\end{array}$ & $\begin{array}{c}0.09908 \\
(139,8.0)\end{array}$ & $\begin{array}{c}0.10609 \\
(139,10.0)^{*}\end{array}$ & $\begin{array}{c}0.13592 \\
(139,12.5)^{*}\end{array}$ \\
\hline $\begin{array}{c}\text { Industry } \\
\text { median-adjusted }\end{array}$ & $\begin{array}{c}0.03363 \\
(278,8.0)\end{array}$ & $\begin{array}{c}-0.01073 \\
(139,-1.0)\end{array}$ & $\begin{array}{c}0.05950 \\
(139,8.5)\end{array}$ & $\begin{array}{c}-0.06013 \\
(139,-5.5)\end{array}$ & $\begin{array}{c}0.11240 \\
(139,6.0)\end{array}$ \\
\hline $\begin{array}{c}\text { Control } \\
\text { group-adjusted }\end{array}$ & $\begin{array}{c}-0.02855 \\
(278,-3.5)\end{array}$ & $\begin{array}{c}-0.03948 \\
(139,-1.0)\end{array}$ & $\begin{array}{c}-0.02455 \\
(139,-3.0)\end{array}$ & $\begin{array}{c}-0.00167 \\
(139,-0.5)\end{array}$ & $\begin{array}{c}-0.06953 \\
(139,-2.0)\end{array}$ \\
\hline \multicolumn{6}{|c|}{ Panel G: Changes in CGSREV } \\
\hline Unadjusted & $\begin{array}{c}0.00065 \\
(274,1.5) \\
\end{array}$ & $\begin{array}{c}-0.00032 \\
(137,-0.5)\end{array}$ & $\begin{array}{c}0.00215 \\
(137,4.0)\end{array}$ & $\begin{array}{c}0.00388 \\
(137,9.0)\end{array}$ & $\begin{array}{c}-0.00815 \\
(137,-8.0)\end{array}$ \\
\hline $\begin{array}{c}\text { Industry } \\
\text { median-adjusted }\end{array}$ & $\begin{array}{c}-0.00230 \\
(274,-10.5) \\
\end{array}$ & $\begin{array}{c}-0.00068 \\
(137,-1.5)\end{array}$ & $\begin{array}{c}-0.00363 \\
(137,-8.0) \\
\end{array}$ & $\begin{array}{c}-0.00075 \\
(137,-3.0)\end{array}$ & $\begin{array}{c}-0.00707 \\
(137,-9.0)\end{array}$ \\
\hline $\begin{array}{c}\text { Control } \\
\text { group-adjusted }\end{array}$ & $\begin{array}{c}0.00028 \\
(271,1.5)\end{array}$ & $\begin{array}{c}0.00028 \\
(136,1.5)\end{array}$ & $\begin{array}{c}0.00124 \\
(135,0.5)\end{array}$ & $\begin{array}{c}0.00108 \\
(136,6.0)\end{array}$ & $\begin{array}{c}-0.00130 \\
(135,-1.5)\end{array}$ \\
\hline \multicolumn{6}{|c|}{ Panel H: Changes in NIREV } \\
\hline Unadjusted & $\begin{array}{c}-0.00528 \\
(274,-11.5)\end{array}$ & $\begin{array}{c}-0.01415 \\
(137,-5.5)\end{array}$ & $\begin{array}{c}0.00037 \\
(137,1.0) \\
\end{array}$ & $\begin{array}{c}-0.01299 \\
(137,-15.0)^{* *}\end{array}$ & $\begin{array}{c}0.00237 \\
(137,1.0)\end{array}$ \\
\hline $\begin{array}{c}\text { Industry } \\
\text { median-adjusted }\end{array}$ & $\begin{array}{c}0.00217 \\
(274,7.0) \\
\end{array}$ & $\begin{array}{c}-0.00158 \\
(137,-1.5) \\
\end{array}$ & $\begin{array}{c}0.00480 \\
(137,7.5) \\
\end{array}$ & $\begin{array}{c}-0.00396 \\
(137,-6.5) \\
\end{array}$ & $\begin{array}{c}0.00832 \\
(137,12.0)^{* *}\end{array}$ \\
\hline $\begin{array}{c}\text { Control } \\
\text { group-adjusted }\end{array}$ & $\begin{array}{c}0.00033 \\
(271,1.0)\end{array}$ & $\begin{array}{c}0.00033 \\
(136,1.0)\end{array}$ & $\begin{array}{c}-0.00132 \\
(135,-3.0)\end{array}$ & $\begin{array}{c}0.00033 \\
(136,1.0)\end{array}$ & $\begin{array}{c}0.00179 \\
(135,1.0) \\
\end{array}$ \\
\hline \multicolumn{6}{|c|}{ Panel D: Changes in ASST } \\
\hline Unadjusted & $\begin{array}{c}-0.02128 \\
(257,-17.5)^{* *}\end{array}$ & $\begin{array}{c}-0.02113 \\
(129,-8.5)\end{array}$ & $\begin{array}{c}-0.02551 \\
(128,-12.0)^{* *}\end{array}$ & $\begin{array}{c}-0.00280 \\
(129,-3.0)\end{array}$ & $\begin{array}{c}-0.03110 \\
(128,-13.0)^{* *}\end{array}$ \\
\hline
\end{tabular}




\begin{tabular}{|c|c|c|c|c|c|}
\hline $\begin{array}{c}\text { Industry } \\
\text { median-adjusted }\end{array}$ & -0.00165 & $\begin{array}{c}0.01748 \\
(257,-1.5)\end{array}$ & $\begin{array}{c}-0.01638 \\
(129,3.5)\end{array}$ & $\begin{array}{c}0.00521 \\
(128,-6.0)\end{array}$ & $\begin{array}{c}-0.00441 \\
(129,3.0)\end{array}$ \\
\hline $\begin{array}{c}\text { Control } \\
\text { group-adjusted }\end{array}$ & 0.00504 & -0.00524 & 0.01165 & -0.01298 & 0.01136 \\
$(254,2.0)$ & $(127,-2.5)$ & $(127,3.0)$ & $(127,-4.5)$ & $(127,3.0)$ \\
\hline
\end{tabular}

\begin{tabular}{|c|c|c|c|c|}
\hline Specifications & $\mathrm{Q}<1$ & $\mathrm{Q}>1$ & To Foreign vendor & To US vendor \\
\hline \multicolumn{5}{|c|}{ Panel A: Changes in SALEFF } \\
\hline Unadjusted & $\begin{array}{l}0.01348 \\
(37,4.5) \\
\end{array}$ & $\begin{array}{c}0.08583 \\
(235,16.5)^{* *}\end{array}$ & $\begin{array}{l}0.01615 \\
(17,0.5) \\
\end{array}$ & $\begin{array}{c}0.11471 \\
(249,15.5)^{* *}\end{array}$ \\
\hline $\begin{array}{c}\text { Industry } \\
\text { median-adjusted }\end{array}$ & $\begin{array}{l}0.04020 \\
(37,0.5)\end{array}$ & $\begin{array}{c}-0.01670 \\
(234,-3.0)\end{array}$ & $\begin{array}{l}0.05445 \\
(17,0.5)\end{array}$ & $\begin{array}{c}0.10268 \\
(249,8.5)\end{array}$ \\
\hline $\begin{array}{c}\text { Control } \\
\text { group-adjusted }\end{array}$ & $\begin{array}{l}-0.41560 \\
(35,-2.0)\end{array}$ & $\begin{array}{c}-0.24830 \\
(233,-7.5)\end{array}$ & $\begin{array}{l}-0.51258 \\
(17,-1.0)\end{array}$ & $\begin{array}{c}-0.36723 \\
(247,-8.0)\end{array}$ \\
\hline \multicolumn{5}{|c|}{ Panel B: Changes in IEFF } \\
\hline Unadjusted & $\begin{array}{c}-0.26623 \\
(37,-7.0)^{* *}\end{array}$ & $\begin{array}{c}0.07454 \\
(235,15.5)^{* *}\end{array}$ & $\begin{array}{l}0.00874 \\
(17,0.5)\end{array}$ & $\begin{array}{c}0.07282 \\
(249,15.0)^{* *}\end{array}$ \\
\hline $\begin{array}{c}\text { Industry } \\
\text { median-adjusted }\end{array}$ & $\begin{array}{l}-0.25936 \\
(36,-4.0)\end{array}$ & $\begin{array}{c}0.05950 \\
(234,11.5)\end{array}$ & $\begin{array}{l}-0.03883 \\
(17,-1.5)\end{array}$ & $\begin{array}{c}0.08482 \\
(248,9.0)\end{array}$ \\
\hline $\begin{array}{c}\text { Control } \\
\text { group-adjusted }\end{array}$ & $\begin{array}{l}0.51062 \\
(35,4.0) \\
\end{array}$ & $\begin{array}{c}-0.13012 \\
(233,-6.0) \\
\end{array}$ & $\begin{array}{l}-0.33547 \\
(17,-2.0) \\
\end{array}$ & $\begin{array}{c}-0.15222 \\
(247,-8.5) \\
\end{array}$ \\
\hline \multicolumn{5}{|c|}{ Panel G: Changes in CGSREV } \\
\hline Unadjusted & $\begin{array}{c}0.01710 \\
(37,7.5)^{*}\end{array}$ & $\begin{array}{c}-0.00221 \\
(235,-5.5)\end{array}$ & $\begin{array}{l}0.01124 \\
(16,1.5)\end{array}$ & $\begin{array}{c}-0.00091 \\
(247,-1.5)\end{array}$ \\
\hline $\begin{array}{c}\text { Industry } \\
\text { median-adjusted }\end{array}$ & $\begin{array}{l}-0.00070 \\
(36,-0.5)\end{array}$ & $\begin{array}{c}-0.00341 \\
(235,-10.5)\end{array}$ & $\begin{array}{l}0.02991 \\
(16,0.5)\end{array}$ & $\begin{array}{c}-0.00113 \\
(247,-4.5)\end{array}$ \\
\hline $\begin{array}{c}\text { Control } \\
\text { group-adjusted }\end{array}$ & $\begin{array}{c}-0.01920 \\
(36,-7.0)^{*}\end{array}$ & $\begin{array}{c}-0.00640 \\
(233,-8.0)\end{array}$ & $\begin{array}{l}0.01493 \\
(16,0.0)\end{array}$ & $\begin{array}{c}0.00169 \\
(247,4.0)\end{array}$ \\
\hline \multicolumn{5}{|c|}{ Panel H: Changes in NIREV } \\
\hline Unadjusted & $\begin{array}{c}-0.01818 \\
(37,-8.5)^{* *}\end{array}$ & $\begin{array}{c}-0.00196 \\
(235,-3.5)\end{array}$ & $\begin{array}{l}-0.05856 \\
(16,-2.5)\end{array}$ & $\begin{array}{c}0.00084 \\
(247,2.5)\end{array}$ \\
\hline $\begin{array}{c}\text { Industry } \\
\text { median-adjusted }\end{array}$ & $\begin{array}{l}-0.00197 \\
(36,-3.0)\end{array}$ & $\begin{array}{c}0.00330 \\
(235,10.5)\end{array}$ & $\begin{array}{l}-0.02781 \\
(16,-2.5)\end{array}$ & $\begin{array}{c}0.00282 \\
(246,8.0)\end{array}$ \\
\hline $\begin{array}{c}\text { Control } \\
\text { group-adjusted }\end{array}$ & $\begin{array}{l}-0.00936 \\
(36,-4.0)\end{array}$ & $\begin{array}{c}0.00283 \\
(232,6.0)\end{array}$ & $\begin{array}{l}-0.00215 \\
(16,-1.0)\end{array}$ & $\begin{array}{c}0.00123 \\
(246,3.0)\end{array}$ \\
\hline \multicolumn{5}{|c|}{ Panel D: Changes in ASST } \\
\hline Unadjusted & $\begin{array}{l}-0.01071 \\
(35,-3.5)\end{array}$ & $\begin{array}{c}-0.02128 \\
(235,-13.5)^{*}\end{array}$ & $\begin{array}{l}-0.07321 \\
(15,-1.5)\end{array}$ & $\begin{array}{c}-0.01768 \\
(247,-11.5) \\
\end{array}$ \\
\hline $\begin{array}{c}\text { Industry } \\
\text { median-adjusted }\end{array}$ & $\begin{array}{l}-0.00108 \\
(35,-0.5)\end{array}$ & $\begin{array}{c}0.00221 \\
(235,0.5)\end{array}$ & $\begin{array}{l}-0.01195 \\
(15,-0.5)\end{array}$ & $\begin{array}{c}-0.00108 \\
(246,-0.5)\end{array}$ \\
\hline $\begin{array}{c}\text { Control } \\
\text { group-adjusted }\end{array}$ & $\begin{array}{l}0.05506 \\
(35,3.0)\end{array}$ & $\begin{array}{c}-0.00359 \\
(232,-1.0)\end{array}$ & $\begin{array}{l}-0.01650 \\
(15,-1.0)\end{array}$ & $\begin{array}{c}0.01363 \\
(246,7.0)\end{array}$ \\
\hline
\end{tabular}


This figure is a year-by-year graph of the frequency of outsourcing deals signed by firms listed on the US markets from 1990 to 2003 (The dotted line is a trend line).

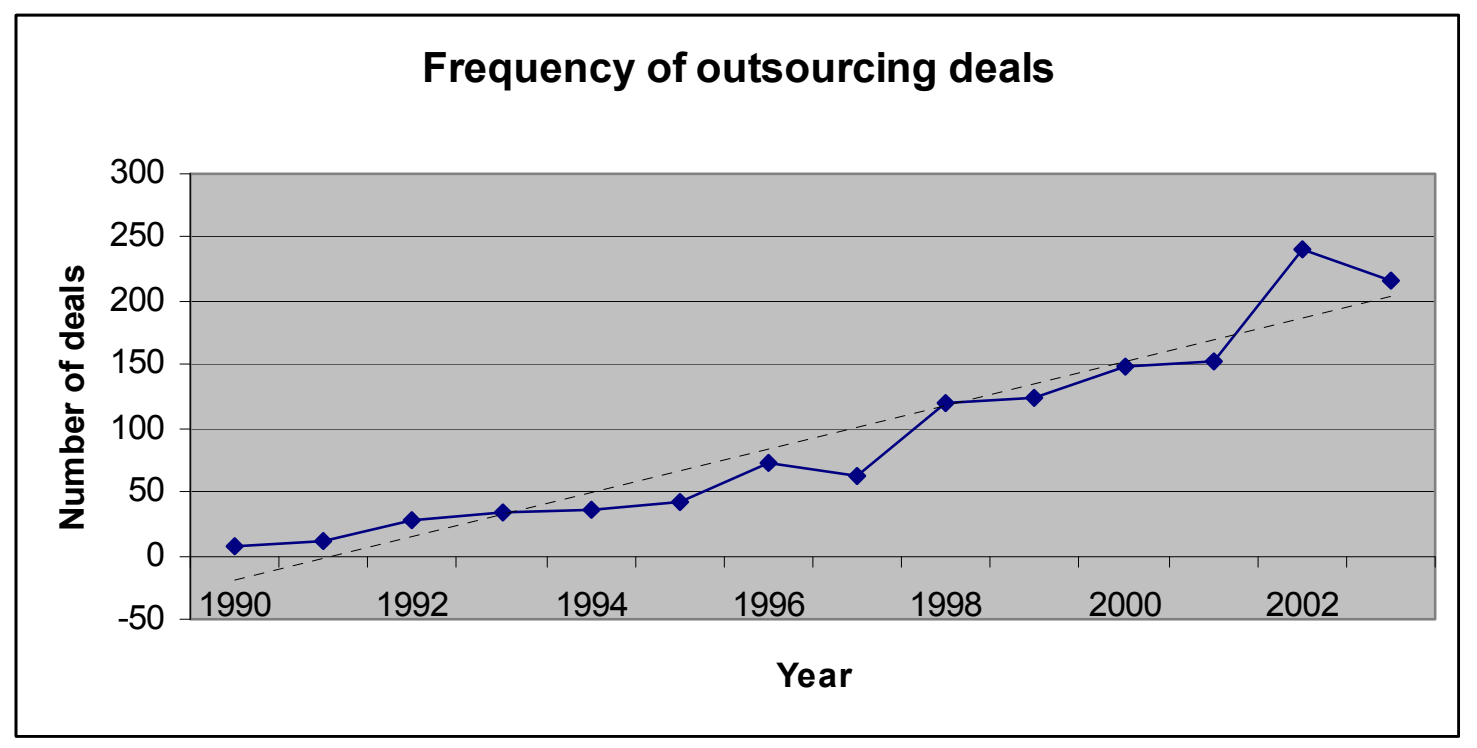

Figure 1. Frequency of outsourcing deals

This figure is a year-by-year graph of the value (in 2000 dollars) of outsourcing deals signed by firms listed on the US markets from 1990 to 2003 (The dotted line is a trend line).

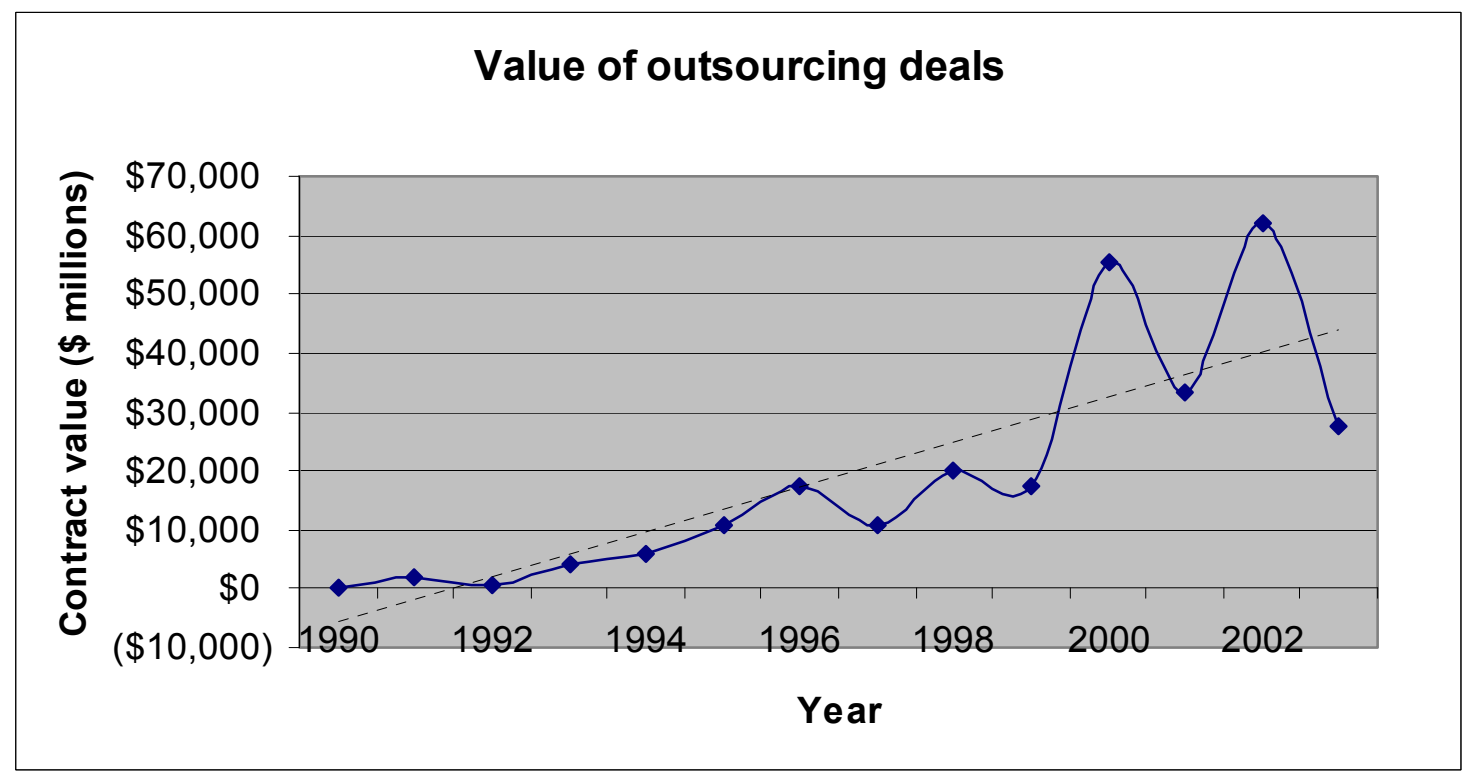

Figure 2. Value of outsourcing deals 